\title{
Unusual Metastatic Site For Nasopharynx Carcinoma: A Case Report
}

\section{Nazofarinks Kanserinde Beklenmedik Bölgeye Metastaz: Olgu Sunumu}

\author{
Ozan Yazici ${ }^{1}$, Mutlu Dogan ${ }^{1}$, Esra Ucaryilmaz ${ }^{2}$, Nurullah Zengin ${ }^{1}$ \\ ${ }^{1}$ Ankara Numune Eğitim Ve Araştırma Hastanesi, Medikal Onkoloji Kliniği, Ankara, Türkiye \\ ${ }^{2}$ Ankara Numune Eğitim Ve Araştırma Hastanesi, Patoloji Kliniği, Ankara, Türkiye
}

DOI: 10.5505/aot.2013.39306

\section{ÖZET}

Nazofarinks bölgesinde en s1k saptanan kanser nazofarinks karsinomudur. Genellikle, lenf nodu metastazı tanı anında ve boyundaki lenf nodu bölgelerinde saptanmaktadır. Nazofarinks kanserinde, nazofarinkste de kitle olmadan uzak lenf nodu metastazı saptanması çok sık görülen bir durum değildir. Kırksekiz yaşında erkek hasta servikal ve sağ aksiller kitle şikayetiyle hastaneye başvurdu. Fizik muayenede bilateral servikal lenf adenopati (LAP) ve sağ aksiller LAP saptand. Servikal LAP eksizyonel biyopsi patolojisinde indiferansiye karsinom metastazı gösterildi. Radyolojik değerlendirmede bilateral servikal LAP, nazofarinkste kalınlaşma ve humerusta kemik metastazı gösterildi. Metastatik indiferansiye karsinom ve primeri nazofarinks olarak kabul edildi ve kemoterapi başlandı. Tama yakın cevap alındı. Dört ay sonra progresyon nedeniyle ikinci basamak tedavi verildi ve tama yakın yanıt elde edildi. Takipte sağ aksiller LAP $(3 \times 2.1 \mathrm{~cm})$ gelişmesi üzerine lenfoproliferatif hastalık gibi diğer etiyolojileri ekarte etmek amacıyla eksizyonel biyopsi yapıldı. Histopatolojik özelliklerin birinci histopatolojik özelliklerle benzer olması nedeniyle keratinize nazofarinks karsinom metastazı düşünüldü. Aksiller LAP metastazı nazofarinks kanserinde nadiren oluşabilmektedir. Özellikle belli bir süredir remisyonda izlenen kanserli hastaları değerlendirirken beklenmedik nüks paterniyle karşılaşılacak olursa ikincil primer tümörler akılda tutulmalıdır. Bu hastalarda ikinci biyopsinin birinci biyopsi ile beraber değerlendirilmesi faydalı olabilir.

Anahtar Kelimeler: Nazofarinks karsinom; Lenf nodu; Aksilla

\begin{abstract}
Nasopharyngeal carcinoma is the most frequent tumor type arising in the nasopharynx. Lymph node metastases are predominantly seen at diagnosis in lymph node regions of neck. Nasopharynx carcinoma presenting with distant lymphadenopathy (LAP) rather than a prominent nasopharyngeal mass is not common. We describe a 48year old man admitted to the hospital with cervical and right axillary mass. In physical examination, he had a $3 \times 2 \mathrm{~cm}$ right axillary lymphadenopathy (LAP) and bilaterally cervical LAPs. An exisional cervical LAP biopsy histopathology revealed undifferentiated carcinoma metastasis. On radiological evaluation, he had bilaterally cervical LAPs and nasopharyngeal thickening and bone metastasis on his right humerus. He was considered as metastatic undifferentiated carcinoma with highly probable primary as nasopharynx carcinoma. He was given chemotherapy. He achieved near complete response. After 4 months of follow-up, he had again second line therapy with near complete remission. In follow-up period, he developed right axillary LAP $(3 \times 2.1 \mathrm{~cm})$. An exisional biopsy of the right axillary LAP was performed to rule out other etiologies, such as lymphoproliferative disease. Histopathology had similar histopathological properties with the first cervical biopsy giving rise to thought of keratinizing nasopharynx carcinoma metastasis. Axillary LAP might occur rarely in nasopharynx carcinoma. Secondary primary tumors should be also kept in mind while evaluating the cancer patients with an unexpected relapsing pattern especially in those followed-up with remission for a while. Evaluation of the second biopsy material with the first one seems to be helpful in these patients.
\end{abstract}

Key words: Nasopharynx carcinoma; Lymph node; Axillary

\section{Introduction}

Nasopharynx carcinoma is a malignancy of nasopharyngeal region. Although it is uncommon malignancy, the epidemiology, histology and clinical features has demonsrated different characteristics compared the other head neck cancers (1). The incidence of nasopharynx cancer shows geographical variation, due to multifactorial etiologies like alcohol consumption, smoking and EpsteinBarr virus (EBV) $(2,3)$. The most common 
presenting symptom of naso-pharyngeal carcinoma is mass in the neck due to cervical lymph node metastasis. However, presentation with lymphadenopathy (LAP) rather than a prominent nasopharyngeal mass is not common. At the time of diagnosis up to $90 \%$ of the cases had metastasis to neck lymph nodes. The location and extend of lymph nodes might predict the distant metastasis (4). Nasopharyngeal carcinoma is commonly metastasis to bone (75\%), liver, lung and distant lymph nodes (5). Axillary lymph nodes are not among the primary lymphatic stations for nasopharyngeal carcinoma (6). A male patient with axillary LAP besides other metastasis and nasopharynx carcinoma is presented in this report.

\section{Case Report}

A 48-year old man admitted to the hospital with cervical and right axillary mass. He had a cervical mass for a year without another comorbidity. In physical examination, he had a $3 \times 2 \mathrm{~cm}$ right axillary lymphadenopathy (LAP) and bilaterally cervical LAPs. He had no other pathology on head and neck examination. An exisional cervical LAP biopsy histopathology revealed undifferentiated carcinoma metastasis with keratinization and a desmoplastic reaction (Fig 1).

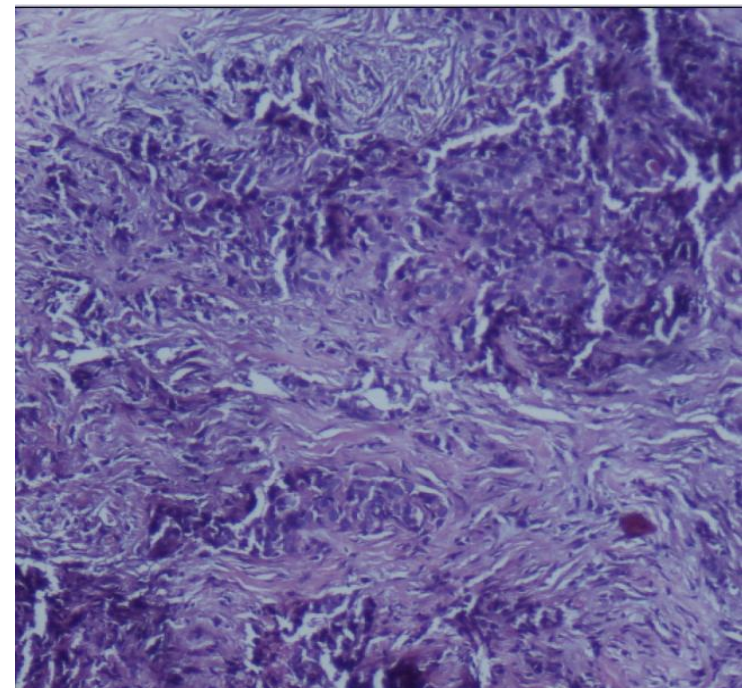

Figure 1: Cervical lymph node biopsy at diagnosis. Keratinization and intercellular bridges with a desmoplastic reaction in response to invasive growth pattern (HE x100)
He had bilaterally cervical LAPs in which the largest one in the right cervical region had a diameter of $3 \mathrm{~cm}$, nasopharyngeal thickening and bone metastasis on his right humerus and pelvis computerized tomography. He had bilaterally cervical LAPs in which the largest one in the right cervical region had a diameter of $3 \mathrm{~cm}$ (SUV max: 12.9), a flu lesion without clear margins in the nasopharynx (SUV max: 16.9) and bone metastasis on his right humerus and pelvis (SUV max: 5.65) on fluorine-18-positron emission computerized tomography (18-F-PET-CT). He was considered as metastatic undifferentiated carcinoma with highly probable primary as nasopharynx carcinoma. He was given platinum, 5-fluorourasil (5FU) and zoledronic acid. He achieved near complete response in the nasopharyngeal thickening and axillary LAP.

After 4 months of follow-up, he had again near complete remission with platinum and taxane for his chemosensitive bilaterally axillary LAPs with diameters of $5 \mathrm{~cm}$. He had bilaterally cervical LAPs with a diameter of smaller than $1 \mathrm{~cm}$ and right axillary LAP $(3 \times 2.1 \mathrm{~cm})$ and liver metastasis after asymptomatic two years. An exisional biopsy of the right axillary LAP was performed to rule out other etiologies, such as lymphoproliferative disease. Histopathology had similar histopathological properties with the first cervical biopsy giving rise to thought of keratinizing nasopharynx carcinoma metastasis (Fig 2).

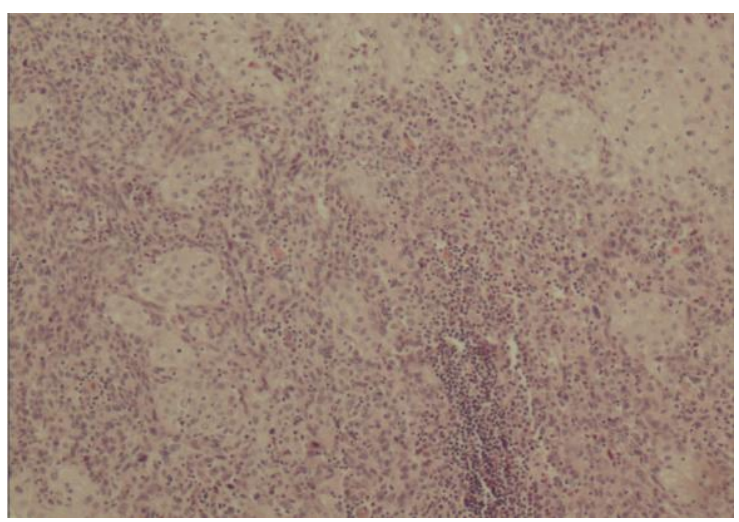

Figure 2: Metastatic axillary lymph node biopsy. Histopathology similar to cervical lymph node biopsy at diagnosis (HE x100) 
It was supported by positive immunhistochemical staining for CK5/6, p63 and EBV (LMP-1) (Fig 3a,b,c). He was again given taxane, platinum and 5FU since he had near complete remission with taxane and platinum 2 years ago. He is being followed-up without progression.
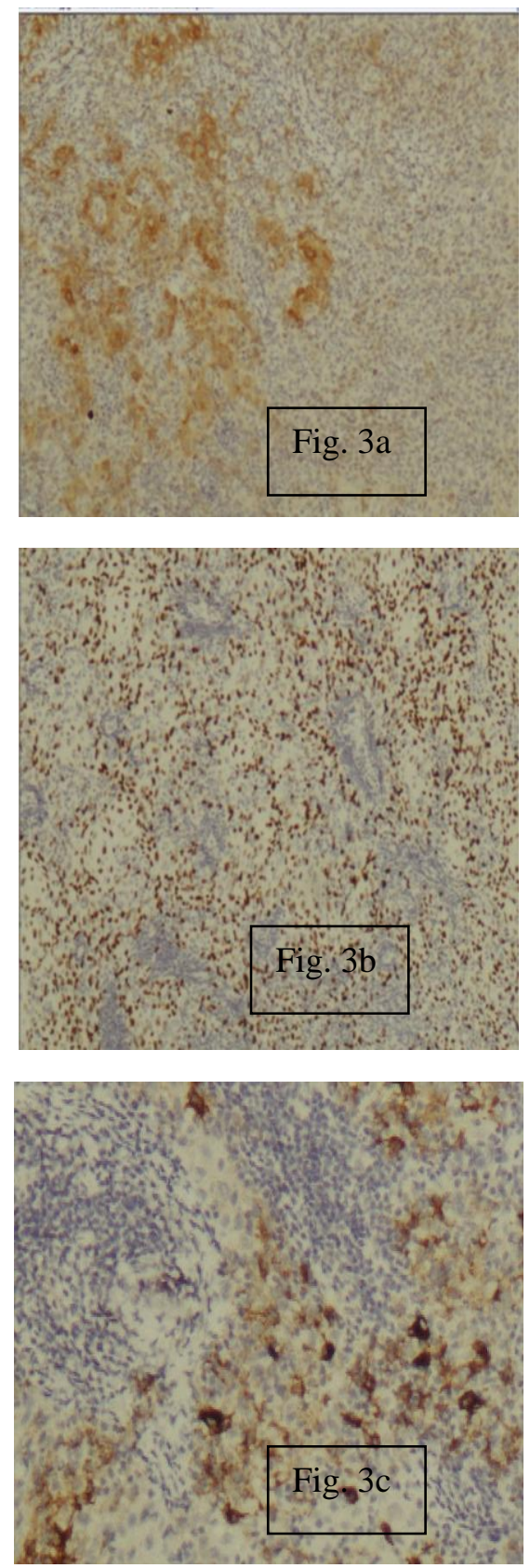

Figure (3a, 3b, 3c): Metastatic axillary lymph node biopsy. Immunpositive for CK 5/6, p63 and EBV (LMP-1). (IHC x100)

\section{Discussion}

Pan et al. demonstrated the lymphatic drainage of the nasal fossa and nasopharynx as the initial lymphatics in the nasal fossa and nasopharynx, the collector lymphatics in the parapharangeal space and the lymph nodes in the lateral pharyngeal and retropharyngeal area (6). Our patient presented with right axillary and cervical LAPs and relapsed with mild cervical and large axillary LAPs after asymptomatic two years. Nasopharyngeal thickenening with high uptake on 18-F-PETCT was determined while evaluating the patient for axillary and cervical LAPs. Right axillary lymphatic region is not defined among the primary lymphatic drainage regions of nasopharynx (6). So, nasopharynx carcinoma is not a common cause of right axillary LAP. Relapsing with prominent axillary LAP despite mild cervical LAPs after a remission period in nasopharynx carcinoma sounds interesting. It is well-known that more common etiologies such as lymphoma should be ruled out while evaluating the patients with LAPs. However, accompanying signs and symptoms should be also taken into account for accurate diagnosis.

In literature it has been reported that there was well-documented link between EBV and undifferentiated nasopharyngeal carcinoma (7). Circulating plasma EBV DNA at the time of diagnosis has been shown to be an independent prognostic factor for survival and for early clinical relapse (8). In a study, patients with high levels of EBV DNA before and after treatment were associated with further distant metastasis (9). In histopathological examination, the presented case also was positively stained with EBV specific markers (Figure 3a-b-c). We thought that the unusual lymph node metastasis and early relapse of our case might be associated with EBV positivity.

In conclusion, the patients with LAPs should be evaluated with accompanying other signs and symptoms in order to have more accurate diagnosis and treatment. Axillary LAP might occur rarely in nasopharynx carcinoma. Secondary primary tumors should be also kept in mind while evaluating the cancer patients with an unexpected relapsing pattern especially in those followed-up with remission for a while. Evaluation of the second 
biopsy material with the first one seems to be helpful in these patients.

\section{Conflict of interest: None}

\section{Referanslar}

1. Ferlay J, Shin HR, Bray F, Forman D, Mathers C, Parkin DM. Estimates of worldwide burden of cancer in 2008: GLOBOCAN 2008. Int J Cancer 2010;127:2893-917

2. Yuan JM, Wang XL, Xiang YB, Gao YT, Ross RK, $\mathrm{Yu}$ MC. Preserved foods in relation to risk of nasopharyngeal carcinoma in Shanghai, China. Int J Cancer 2000;85:358

3. Liebowitz D. Nasopharyngeal carcinoma: the Epstein-Barr virus association. Semin Oncol 1994;21:376

4. Liao XB, Mao YP, Liu LZ, et al. How does magnetic resonance imaging influence staging according to AJCC staging system for nasopharyngeal carcinoma compared with computed tomography? Int $\mathrm{J}$ Radiat Oncol Biol Phys 2008;72:1368

5. Altun M, Fandi A, Dupuis O, Cvitkovic E, Krajina $\mathrm{Z}$, Eschwege F. Undifferentiated nasopharyngeal cancer (UCNT): current diagnostic and therapeutic aspects. Int J Radiat Oncol Biol Phys 1995;32:85977

6. Pan WR, Suami H, Crlett RJ, Ashton MW. Lymphatic drainage of the nasal fossae and nasopharenx: Preliminary anatomical and radiological study with clinical implications. Head Neck 2009;31:52-7

7. Dolcetti R, Menezes J. Epstein-Barr virus and undifferentiated nasopharyngeal carcinoma: new immunobiological and molecular insights on a longstanding etiopathogenic association. Adv Cancer Res 2003;87:127-57

8. Chu EA, Wu JM, Tunkel DE, Ishman SL. Nasopharyngeal carcinoma: the role of the EpsteinBarr virus. Medscape J Med. 2008;10:165

9. Hou X, Zhang L, Zhao C, et al. Prognostic impact of plasma Epstein-Barr virus DNA concentration on distant metastasis in nasopharyngeal carcinoma]. Ai Zheng 2006;25:785-92 